
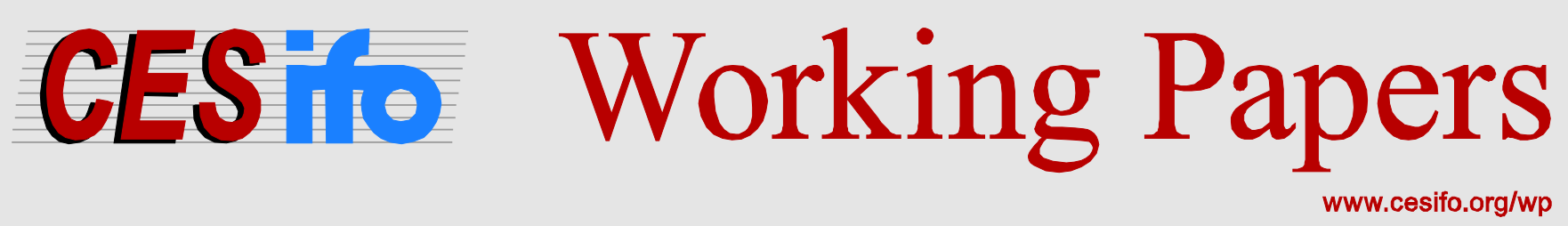

\title{
Natural Disasters, Government Spending, and the Fiscal Multiplier
}

\author{
Jan Fidrmuc \\ Sugata Ghosh \\ Weonho Yang
}

\author{
CESIFO WORKING PAPER NO. 5665 \\ CATEGORY 6: FisCAL POLICY, MACROECONOMICS AND GROWTH \\ DECEMBER 2015
}

An electronic version of the paper may be downloaded

- from the SSRN website:

- from the RePEc website:

- from the CESifo website:

WwW.SSRN.com

Www.RePEc.org

www.CESifo-group.org/wp

\section{CESifo}




\title{
Natural Disasters, Government Spending, and the Fiscal Multiplier
}

\begin{abstract}
We estimate the fiscal multiplier associated with shocks to government spending. We consider increases in government spending in the U.S. states in the wake of natural disasters to capture spending shocks that are both unexpected and unrelated to the preceding state of the economy. We find that these have a powerful stimulating effect on the local economy, which is reflected in the value taken by the fiscal multiplier. This result is obtained when we identify fiscal shocks by the states' own exposure to natural disasters, or when we use nearby states' exposure to disasters instead.
\end{abstract}

JEL-Codes: E220, E620, H300, H500, H720.

Keywords: natural disasters, government spending, fiscal multiplier, U.S. states.

Jan Fidrmuc*
Department of Economics and Finance
Brunel University
UK-Uxbridge, UB8 3PH
Jan.Fidrmuc@brunel.ac.uk or jan@fidrmuc.net
Sugata Ghosh
Weonho Yang
Department of Economics and Finance
Brunel University
UK-Uxbridge, UB8 3PH
sugata.ghosh@brunel.ac.uk

*corresponding author

October 2015

This research was initiated while Weonho Yang was a $\mathrm{PhD}$ student at Brunel University, whereby he was supported by a partial scholarship from the Ministry of Strategy and Finance of the Republic of Korea. He gratefully acknowledges the Ministry's generosity. We are grateful for helpful comments and suggestions received from seminar participants at National Bank of Slovakia. 


\section{Introduction}

Fiscal spending and its effects on the economy have received renewed attention recently in the context of the global economic and financial crisis and the European debt crisis. In this context, assessing the effectiveness of government spending, embodied in estimates of the fiscal multiplier, is of critical importance. Although the size of the fiscal multiplier is one of the most fundamental questions in macroeconomics, it also remains one of the most controversial ones. Different schools of thought (neoclassical vs new-Keynesian, most notably) and different methods (econometric vs narrative or quasi-experimental) tend to produce often widely diverging answers. This can have important policy implications: assuming a low multiplier would make one conclude that fiscal stimulus programs (austerity measures) will have only a modest positive (adverse) economic impact. Conversely, a relatively high estimate would imply that fiscal stimuli can bring about substantial economic benefits while fiscal adjustments can set the economy back considerably.

In principle, the underlying question is simple: by how much does aggregate output increase following a $\$ 1$ increase in government spending? Standard time-series econometrics can be used to find the answer if, and only if, the changes in government spending considered are both exogenous with respect to economic growth and unanticipated. These assumptions, however, are often violated. Changes in government spending resulting from the working of automatic stabilizers (progressive taxes, unemployment benefits, welfare spending and the like) are, by construction, counter-cyclical and therefore closely correlated with economic growth. The austerity measures imposed in Greece and other Eurozone countries due to their excessive debt, on the other hand, are pro-cyclical. Finally, rational agents would internalize the effects of a pre-announced change in government spending well before the change actually takes place and therefore the measured impact of such a change would be confounded by anticipation effects.

To solve this quandary requires making (sometimes arbitrary) assumptions and imposing restrictions on time lags and on various elasticities (see Blanchard and Perotti, 2002, Perotti, 2005; Giordano et al., 2007, Mountford and Uhlig, 2009; Auerbach and Gorodnichenko, 2012; and others), or following the so-called narrative approach based on identifying natural experiments where government spending increases suddenly and unexpectedly in a manner independent of the business cycle. To date, changes in military spending (sometimes combined with contemporaneous professional forecasts of government spending) due to military conflicts or expectations thereof have proven particularly popular as sources of exogenous and unexpected changes in government spending (Ramey and Shapiro, 1998; Burnside et al., 2004; Ramey, (2011a); Barro and Redlick, 2011). The evidence produced by those studies suggests that the fiscal multiplier is rather low: close to, and possibly even below, one. There is also a small but growing literature using other approaches, not based on military spending, to identify unanticipated fiscal shocks. Serrato and Wingender (2010) use 
changes in allocations of federal spending to states caused by population changes identified by means of the Census every 10 years. Their estimates imply that government spending has a local income multiplier of 1.88. Shoag (2010) collects a new dataset on the returns of state pension plans which can predict subsequent state government spending. He shows that state government spending has a large positive effect on in-state income with a multiplier of 2.11. Fishback and Kachanovskaya (2010) use political competiveness across states to estimate the effects of New Deal spending and find a multiplier of 1.7. At the local level, Nakamura and Steinsson (2011) use military spending data for U.S. regions to estimate the effects of government spending. Finally, Acconcia, Corsetti and Simonelli (2014) use the Italian rule requiring that local councils that were proven to be infiltrated by organized crime are replaced by appointed administrators. This typically results in a precipitous fall in local government expenditure: they use this to estimate a local fiscal multiplier of $1.5 .^{3}$

In this paper, we suggest a new instrument for fiscal shocks: increases in government spending in the wake of natural disasters. Natural disasters are relatively frequent events; yet, by definition, they are unexpected and unrelated to the prior state of the economy. Importantly, governments respond to natural disasters by spending on relief and reconstruction, as well as on precautions against future calamities. ${ }^{4}$ Because natural disasters are typically limited in their geographic scope, we consider the regional (US state level) rather than country-wide economic effects of government spending (nevertheless, we address the latter in the companion paper, Fidrmuc, Ghosh and Yang, 2015). To this effect, we collect an extensive data set on economic damages due to natural disasters, state-level fiscal spending and other relevant macroeconomic variables for all 50 US states. We then use damages due to natural disasters to identify exogenous and unexpected changes in government spending in a way akin to that pursued by the literature utilizing military spending.

An important issue in the context of natural disasters is the fact that natural disasters may also have a considerable impact on the local economies on their own: through destruction of commercial and private property, loss of life, displacement of population (whether temporary or permanent), and the like. To deal with this, we replicate our analysis also while replacing the states' own economic damages with those incurred in nearby states as an instrument for the changes in government spending at the state level. Given their nature, natural disasters are rarely limited to a single state. The economic damage suffered by any given state is typically

\footnotetext{
3 See Fuschs-Schündeln and Hassan (2015, Section 3) for an overview of the narrative and quasi-experimental literature.

${ }^{4}$ In the wake of Hurricane Katrina, the US Congress approved \$14.6 billion to build new levies and floodgates in New Orleans (see "Beyond the walls," The Economist, Sept 1, 2012). Similarly, the reconstruction in the wake of Hurricane Sandy was expected to "serve as a mini-stimulus for the regional economy" ("Wild is the Wind," The Economist, Nov. 3, 2012). Some estimates have the cost of building new levies and storm-surge barriers to protect New York and New Jersey from future storms as high as $\$ 30$ billion. ("Can New York become New Amsterdam again?", The Economist Gulliver Blog, Nov. 5, 2012, http://www.economist.com/blogs/gulliver/2012/11/defending-new-york-floods.)
} 
a good (though not perfect, see Yang, Fidrmuc and Ghosh, 2012a/b) predictor of the size of the ensuing increase in government spending in that state. The damages incurred by nearby states, in contrast, should predict rather well whether the state in question was afflicted by a natural disaster, but much less so the size of the fiscal response. We consider nearby states as those whose state capital cities are within $1000 \mathrm{~km}$ from the state capital (straight-line distance). Furthermore, we weigh the economic damages in nearby states by the inverse of distance. $^{5}$

There is a sizeable literature on the short- and long-run impact of natural disasters. Noy (2009) analyzes the effects of natural disasters on output in the short-run and shows that countries with a higher literacy rate, better institutions, higher per capita income, higher degree of openness to trade, higher levels of government spending, more foreign exchange reserves and higher levels of domestic credit, but with less open capital accounts, are able to withstand the initial shock better and avoid spillovers into the wider economy. Raddatz (2009) shows that smaller and poorer countries are more vulnerable, especially to climatic disasters, and that the level of external debt has no relation to the output impact of any type of disaster. Loayza et al. (2009) find that while small disasters may have a positive effect due to the reconstruction efforts, large disasters have severe negative impact on the economy immediately. Skidmore and Toya (2002) and Crespo et al. (2008), in contrast, examine the long-run impact of natural disasters on growth. They suggest that a higher frequency of natural disasters is associated with higher growth rate in the long-run in a process akin to 'creative destructions': older physical assets and technologies tend to be more prone to destruction during natural disasters. They are therefore likely to be replaced in the wake of natural disasters by more advanced assets and technologies.

A limited number of papers examine the fiscal impact of natural disasters. Lis and Nickel (2009) explore the impact of large-scale extreme weather events on changes in budget balances in country groups. They conclude that natural disasters increase the budget deficits in developing countries, while no significant effects are found for advanced countries. Melecky and Raddatz (2011) estimate the impact of different types of natural disasters on government expenditures, revenues and fiscal deficits for high- and middle-income countries, employing a panel vector autoregressive model. They conclude that disasters have an important negative impact on the fiscal stance by decreasing output and increasing fiscal deficits, especially for low- and middle-income countries. Moreover, they find that countries with more developed financial or insurance markets suffer less from disasters in terms of output declines. Finally, Noy and Nualsri (2011) estimate the fiscal consequences of natural disasters using a panel vector autoregressive model. They find that fiscal behavior in the

\footnotetext{
5 In relying on the spatial dimension of natural disasters, our analytical approach is similar to that of Jackson (2014) who uses the increase in inflows of foreign aid to assess the impact of aid on growth. He uses the aid receipts of countries sharing the same donor (which he defines as 'aid neighbors') to instrument the aid inflows into the country in question.
} 
aftermath of disasters to be counter-cyclical in developed countries, but pro-cyclical in developing countries.

Our paper has two main results. First, we demonstrate that natural disasters can be used to identify government spending shocks. Although we carry out our analysis for the US, a similar analysis could easily be executed for other countries. Second, our estimates of the fiscal spending multiplier obtained with the states' own exposure to natural disasters range between 1.5 and 2.5. This suggests that increases government spending have a sizeable stimulating effect on the local economy. The estimates obtained when using nearby states' exposure to natural disasters as an instrument are higher, between 4 and 7. Although these appear too high, we discuss the potential reasons for this in the remainder of the paper.

The paper is organized as follows. Section 2 describes the natural disaster series, its construction and properties. Section 3 explains our estimation strategy and reports the results of our empirical analysis. Section 4 subjects the baseline results to a number of robustness checks. Finally section 5 concludes.

\section{Natural disasters in the U.S.}

A key source of information on natural disasters, their frequency and impact is the Emergency Disasters Database (EM-DAT) maintained by the Center for Research on the Epidemiology of Disasters (CRED) in Brussels. Figure 1, based on their data, suggests that the frequency of natural disasters in the U.S. has been increasing in the last few decades. Similarly, the Federal Emergency Management Agency (FEMA) which coordinates the response to disasters in the U.S., has recorded an upward trend in the annual number of presidential disaster declarations (also included in Figure 1). On average, there were 25.2 presidential disaster declarations per year in the 1980s, compared to 84.7 declarations on average since 2000 .

After a natural disaster, the federal, state and local governments respond cooperatively, following the Federal Response Plan and other applicable laws. ${ }^{6}$ The local government has the primary responsibility for responding to, recovering from and mitigating the adverse effects of the disaster. However, when the effects of the disaster are beyond the capacity of the local resources to respond to effectively, the state and federal government assistance is provided through the emergency and disaster declaration process. ${ }^{7}$ A presidential disaster declaration triggers action by additional federal agencies besides FEMA, including the U.S. Army Corps of Engineers, the Small Business Administration, and the Departments of Agriculture, Transportation, Commerce and others, to provide supplemental assistance to state and local governments. Under the Stafford Act, many disaster relief costs are shared

\footnotetext{
${ }^{6}$ For example, there are the Robert T. Stafford Disaster Relief and Emergency Assistance Act (Stafford Act) for federal assistance and Natural Disaster Assistance Act (NDAA) for state assistance.

7 There are three types of declaration: local emergency declaration, Governor's state of emergency proclamation and Presidential declaration of a federal major disaster or emergency.
} 
between the federal government and the concerned state and local governments. The federal share of funding is at least $75 \%$ of the public assistance. However, depending on the circumstances, the federal government can raise the federal share: it was 90\% for the 1994 Northridge earthquake and 100\% for the 1992 Hurricane Andrew (Czerwinski, 1998). The state and local government spending in the wake of natural disasters therefore relies not only on state/local fiscal capacity but includes also grants from the federal government.

To construct our instrument for state-level government spending, we rely on the aforementioned EM-DAT database. This constitutes an initial filter to ensure that we are considering natural disasters large enough to elicit a change in government spending. In order to be entered into the EM-DAT database, a disaster must meet at least one of the following criteria: 10 or more people killed; 100 or more people affected; a declaration of a state of emergency; or a call for international assistance. We select the period from 1977 to 2009 in order to minimize the possibility that our results are confounded by fluctuations of government spending due to military build-ups: defense spending accounts for a lion's share of federal government expenditure. By choosing this period, we exclude the U.S. involvement in World War II, Korean War and Vietnam War. We complete the list of major disasters and economic damages at the national level by cross-checking the EM-DAT database with the lists of presidential major disaster declarations from FEMA and with the list of climate-related disasters with damages exceeding one billion dollars from the National Ocean and Atmospheric Administration (NOAA). In order to compile the data on natural disasters, we proceed in two steps. First, we collect the total economic damages per natural disaster at the national level. Second, we allocate the economic damages to the 50 states to be used in a panel analysis at the state level.

The next step is to distribute the total economic damages per disaster to each state affected. As far as we know, there is no systematic and comprehensive data on this because economic damages at the state-level are not consistently reported. Therefore, we construct state-level economic damage series from various sources with several criteria applied in sequence. ${ }^{8}$ First, we consider the disaster reports issued by the National Hurricane Center, National Weather Service, or the Storm Prediction Center. Most of these reports were written at the time of incidence so they match the government spending shocks which are the primary variable of interest in this paper. In the case of disasters with no report, we rely on the storm event database of the National Climate Data Center ${ }^{9}$, EM-DAT, U.S. Geological Survey, and

\footnotetext{
${ }^{8}$ The sources include EM-DAT, the Storm event database of the National climate data center, the National Hurricane Center, the National Weather Service, the Federal Emergency Management Agency, U.S. Department of Agriculture, individual state emergency management agencies, state and regional climate centers, Geological Survey reports, U.S. Army Corps of Engineers reports, media reports and insurance industry estimates (Appendix B).

${ }^{9}$ The database currently contains data on property and crop damage in millions of dollars from 1996 to present. However, prior to 1996, it shows only range of damage. Therefore, we use the data from this database directly since 1996, but before 1996 we just consult it as a means of the ratio for distributing total economic damages to each state.
} 
U.S. Army Corps of Engineers. Lastly, for some natural disasters only total damage but no damage data by state is available: in such cases, we distribute the aggregate damages according to the ratios of other data such as financial assistance grant from FEMA, the number of counties where emergency was declared, the number of deaths, and so on.

To analyze the effects of government spending shocks related to natural disasters, it is necessary to transform the economic damages into time series. Since only annual fiscal data are available at the state level, we allocate the economic damages to fiscal years. ${ }^{10}$ Once the natural disaster occurs, the presence of fiscal policy lags implies that the state government needs time to respond and allocate funds towards relief and recovery efforts. In case of major natural disasters, before the presidential disaster declaration is issued, the damage needs to be surveyed to determine eligibility for assistance. The lag for disaster declaration is usually 1 week (although in some cases it was several months). Therefore, we use the date of the declaration as the date of the associated government spending shock, and allocate it into appropriate fiscal year; if the disaster declaration occurs in the last week of the fiscal year, it is assigned to the next year. Lastly, we deflate the nominal economic damages using CPI $(2005=100)$.

Table 1 shows the basic statistics for disaster damages per state from FY 1977 to FY 2009 in the five states with greatest incidence of natural disasters. In terms of frequency per year, Texas has experienced major disasters more often than any other state, followed by California, Oklahoma, and Louisiana. On the other hand, the state with the greatest annual damage is Florida with $\$ 6.1$ billion (not included in the table), followed by Louisiana ( $\$ 4.5$ billion) and California ( $\$ 2.7$ billion).

\section{State-level effects of government spending shocks in the US}

\subsection{Data}

The data on state government expenditure, revenues, and public debts are taken from the U.S. Census Bureau's Economic Statistics on state government finances, available from 1977 to 2009 (fiscal years, there are no quarterly fiscal data for the states of the U.S.). We use the general fiscal data: the expenditures include all cash payments for goods and services including subsidies, and the revenues consist of all income including intergovernmental revenues such as grant from the federal government. ${ }^{11}$ For the state government debt, both short and long term debt are included.

\footnotetext{
${ }^{10}$ In the U.S. while the fiscal year of the federal government starts on Oct 1st and ends on the following Sep 30th, the fiscal years of the 50 states are different from each other. 46 of the 50 state governments have a fiscal year that runs from July 1st until June 30th. Four states are exceptions: Alabama and Michigan (Oct.1st Sep.30th), New York (Apr.1st Mar.31th) and Texas (Sep.1st Aug.31th).

${ }^{11}$ General expenditure and general revenues comprise all types of expenditure and revenues, excluding special accounts: utility, liquor stores, and insurance trusts.
} 
As the state-level output variable, we use personal income instead of the gross state product (GSP). The reason is that unlike GSP, personal income data are available at the quarterly frequency, which makes it possible to attribute personal income data to fiscal years. ${ }^{12}$ Other state-level variables that we use include the house price index as a proxy for inflation from the Federal Housing Finance Agency (FHFA), and non-farm payroll employment data from the Bureau of Labor Statistics (BLS). The Coincident Economic Activity Index (CEAI), which is set to match the trend for GSP by including four indicators, non-farm payroll employment, the unemployment rate, average hours worked in manufacturing and wages and salary, is taken from the Federal Reserve Bank (FRB). We obtain total mid-year state population data from the Census Bureau. The national consumer price index (CPI) for urban consumers is taken from the BLS. ${ }^{13}$

All macroeconomic variables are attributed to the appropriate fiscal year in order to match the fiscal variables. All except index variables are in real per capita terms, deflated by the CPI $(2005=100)$. Finally, all variables are expressed in logs.

\subsection{Methodology}

To estimate the macroeconomic effects of government spending shocks related to natural disasters, we formulate a panel vector autoregressive (PVAR) model for the 50 states during 33 fiscal years from 1977 to 2009 . For a given state, the reduced form equation is as follows:

$$
Y_{i, t}=A_{0}+\sum A_{j} Y_{i, t-j}+\sum B_{j} D_{i, t-j}+\theta_{i}+\gamma_{i} t+e_{t},(i: \text { state })
$$

where $Y_{i, t}=(\operatorname{Exp}, P I, \operatorname{Rev}, H P I, E m p)^{\prime}$ is a vector of endogenous variables including government expenditure (Exp), Personal Income $(P I)$, Revenues (Rev), House Price Index (HPI), and Employment (Emp). $D_{i}$ stands for economic damages due to natural disasters as the exogenous fiscal-shock variable. $\theta_{i}$ is a vector of state fixed effects, $\gamma_{i}$ is a vector of state time-trends, and $e_{t}$ is a vector of reduced form innovations that are assumed to be independently and identically distributed (i.i.d.). Other variables of interest such as Debt replace Employment one at a time. ${ }^{14}$ Similar to other studies on the effects of fiscal shocks such as Burnside et al. (2004) and Ramey (2011a), the identification assumptions are that natural disasters of states are exogenous and that among the endogenous variables in the vector $Y_{i, t}$, a variable that comes earlier in the ordering is more exogenous than those that appear later. ${ }^{15}$ In addition, following Ramey (2011a), we transform the equation (1) and embed the natural disaster variable as endogenous in the PVAR, but order it first before the other variables: ${ }^{16}$

${ }^{12}$ U.S. Bureau of Economic Analysis (BEA) provides only annual GSP data, and GSP is subject to a break in 1997 because of change in industry classification from SIC to NAICS.

13 Appendix B describes the data sources in full detail.

${ }^{14}$ In many analyses of fiscal policy, additional variables such as the interest rate are often included to control for monetary policy. However, in this baseline specification, such a variable is not included because fiscal policy shocks are observed at the state level, not national level, and the data is annual.

15 This particular ordering is known as 'Choleski Ordering'.

${ }^{16}$ We thank Valerie Ramey for informing us (via personal communication) that the results are similar when the 


$$
X_{i, t}=A_{0}+\sum A_{j} X_{i, t-j}+\theta_{i}+\gamma_{i} t+e_{t}, \text { where } X_{i, t}=\left(D_{i, t}{ }^{\prime}, Y_{i, t^{\prime}}\right)^{\prime}
$$

As suggested by Love and Zicchino (2006), before equation (2) can be estimated, the original variables need to be detrended and the state fixed effects need to be eliminated by forward mean-differencing which is known as the 'Helmet procedure'. ${ }^{17}$ To check the stationarity of adjusted variables, several panel unit root tests are performed and the results show that all variables are stationary. ${ }^{18}$ Finally, 2 annual lags are selected as being optimal based on the SBIC and HQIC criteria. ${ }^{19}$

We estimate equation (2) by using the generalized method of moments (GMM) and then compute the impulse-response function (IRF) to one standard deviation shock attributable to the natural disaster. ${ }^{20}$ The confidence interval is $68 \%$, obtained using Monte Carlo simulations which generate the 16th and 84th percentiles of the distribution with 1000 repetitions. $^{21}$ All responses are multiplied by 100 so that the growth rate from the change in log variables is expressed in percent $(\%)$.

To ensure that our results are not driven by the direct effects of natural disasters, we report also the results of an estimation in which we replace $D_{i}$ in equation (1) by economic damages due to natural disasters in nearby states. We define nearby states as those within $1000 \mathrm{~km}$ straight-line distance (considering distance between state capital cities). We have to exclude Alaska and Hawaii from this part of our analysis, as they do not have any nearby states (we do not consider Canadian or Mexican provinces when constructing this instrument). Natural disasters are rarely limited to a single state, so that nearby states' exposure to natural disasters should be a good predictor of whether the state in question is likely to experience a fiscal shock caused by a natural disaster. At the same time, the states' degree of exposure is likely to vary, and the overall amount of damages is bound to depend on state characteristics such as size, population, degree of urbanization and the like. Therefore, the extent of damages suffered by nearby states will explain the incidence of fiscal shocks well, but should not be too closely correlated with the damages incurred by the home state.

\subsection{Results}

Figure 2 shows the impulse response functions of fiscal and macroeconomic variables to fiscal shocks identified using state's own economic damages. ${ }^{22}$ The impulse responses

exogenous variable is treated as exogenous, or when it is embedded first in a VAR. We explored both methods with her data and, indeed, obtained very similar results.

17 Love and Zicchino (2006) argue that the fixed effects are correlated with the regressors due to lags of the dependent variables, so that mean-differencing procedure would create biased coefficients. Forward meandifferencing removes only the forward mean so that it can preserve the orthogonality between transformed variables and lagged regressors.

${ }^{18}$ We use 6 types of unit tests using the STATA software: Levin-Lin-Chu test, Harris-Tzavalis test, Breitung test, Im-Pesaran-Shin test, Fisher-type tests, and Hadri LM stationarity test.

${ }^{19}$ Since there is no standard procedure for lag selection under PVAR in STATA, this selection is done in EViews. As a robustness check, 1 and 3 lags are also considered. The results are very similar.

20 We use the STATA package by Love and Zicchino (2006) for this estimation.

21 Results with $90 \%$ confidence bands are reported in Appendix C.

${ }^{22}$ The shock is normalized as one standard deviation in damages due to natural disasters, the response is 
suggest that government spending increases have a strong positive effect on the local economy. After a natural disaster, government expenditure increases in a hump-shaped pattern, peaking in the second year and remaining significantly positive for 10 years. The effect on personal income is twin-peaked: the first peak appears on impact, followed by another peak in the second year after the shock; the income response remains significantly positive for six years. The next graph shows the response of government revenues to the spending shock. Revenues usually follow the response of output because tax receipts closely depend on the state of the economy. However, in this case, revenues increase on impact, peaking during the first year, that is, before income peaks. Thereafter, revenues follow a pattern similar to those of personal income and government expenditure. This confirms that the main source of the rise in government revenues (and, correspondingly, the rise in spending) is not local taxes or borrowing but transfers from the federal government. The positive response of government debt supports this interpretation: debt responds little during the first year after the shocks. The house price index, which we use as a proxy for the local price level, remains significantly positive for five years, similar to the response of personal income. Finally, employment initially falls slightly, which may be due to the negative direct impact of the natural disaster. This is followed by a positive but barely significant response, which peaks in the third year.

In Figure 3, we present the impulse response functions obtained using damages in nearby states as an instrument to identify local government spending shocks. The responses of all six variables are very similar. The main exception is personal income, whose response is now hump-shaped, and employment, which rises sharply after the shock and remains positive for five years.

It is usually instructive to summarize the effect of fiscal shocks by estimating the corresponding fiscal multiplier. When using the states' own damages, the peak elasticity of personal income to government expenditure in the second year is 0.39 , and the cumulative elasticity ten years after the shock is 0.17 (Panel A of Table 2). The average ratio of personal income to state government expenditure from 1977 to 2009 is 8.35 . The resulting estimate of the peak income multiplier (attained in the second year) then is 2.48 while the cumulative multiplier (after ten years) is 1.45. These figures fall roughly within the range of 1.5 to 3.0 of the other cross-state analyse ${ }^{23}$ but exceed the multipliers obtained with military buildups, between 0.6 and $1.5 .^{24}$ The multipliers obtained with nearby states' damages (using the elasticities in Panel B or Table 2 and taking into account that the average ratio of personal income to government expenditure when omitting Hawaii and Alaska is 8.50) are higher: the

percentage deviation from a variable's baseline path, and Figure 1 (as well as all subsequent figures) feature 68\% confidence bands obtained by Monte Carlo simulation with 1000 replications.

${ }^{23}$ These are 2 (Shoag, 2010), 0.3 3 (Clemens and Miran, 2011), 1.5 (Nakamura and Steinsson, 2011) and 1.88 (Serrato and Wingender, 2011).

${ }^{24}$ Specifically, these are 0.6 0.9 (Baro-Redick, 2011), 0.6 1.2 (Ramey, 2011a), 0.9 1.29 (Blanchard-Perotti, 2002), and 1.5 (Fisher-Peters, 2010). See also the overview in Ramey (2011b). 
peak one (in the third year) is 7.06 while the cumulative (10 years) is 4.03 . These latter figures are considerably higher than most multipliers reported in the literature.

Several aspects of the analysis should be considered when interpreting the above figures. First, state-level multipliers associated with spending shocks after natural disasters are qualitatively different from national ones. This is because, as discussed above, the bulk of the expenditure is financed by grants from the federal government. Such grants present, from the state's point of view, essentially free money, as the resulting future tax burden will be shared across all 50 states. Standard economic theory predicts a higher multiplier in this case than in the aggregate case (see Ramey, 2011b, section 4).

Second, we are restricted by data availability to use personal income whereas other studies typically use GDP or GNP. Furthermore, we look at the shocks to state fiscal spending rather than to federal spending: in the US, federal spending is much higher than state spending. This leads to the ratio of personal income to spending being relatively high, 8.35. The corresponding ratio of aggregate GDP to federal government spending is 4.7 over the same period (see Fidrmuc et al., 2015). Using state spending and personal income therefore also contribute to the multiplier being relatively high. Together with the aforementioned fact that much of the spending is financed by federal grants, they also imply that the estimates obtained with this particular method should not be seen as directly comparable with estimates obtained by following a different approach and using different data.

A final consideration reflects the nature of the relationship between home-state fiscal shocks and natural disasters in nearby states. Natural disasters in nearby states have two kinds of impacts on the home state. ${ }^{25}$ When a natural disaster takes place in the close geographical proximity of the state, the home state is likely to be affected by the same disaster. This was our primary motivation for using nearby states' damages to identify the incidence of fiscal shocks: However, even when the natural disaster does not affect the home state, the state is likely to experience spillover effects in terms of increased demand for relief supplies and labor (food and medical supplies, fuel, relief workers, and the like) and to receive an influx of temporarily displaced people from the affected states who need to be housed and taken care of. Such demand spillovers then lead to increased income in the home state, without the state experiencing any concurrent adverse effects due to the natural disaster. Earnings of labor engaged in nearby states, furthermore, gets counted in the home state's personal income whereas even when it would normally be included in the nearby state's output statistics. These aspects of natural disasters in nearby states would also contribute to the multiplier obtained with nearby states' damages being higher.

\footnotetext{
${ }^{25}$ In fact, natural disasters in nearby states explain fiscal shocks better than states' own damages: regressing government spending on two lags of nearby states' damages due to natural disasters explains $13 \%$ of the variance, with an F-statistic of 58, while using the states' own damages (two lags again) explains $4 \%$ and the Fstatistic is 15 .
} 
Hence, while we cannot directly compare our multiplier estimates with those that we would obtain had we used GDP and overall spending, our results suggest that fiscal shocks have a powerful stimulating effect on the local economy. Nevertheless, in the companion paper, Fidrmuc et al. (2015), where we consider the effect of spending shocks at the national level, such cross-state fiscal spillovers should cancel out. Indeed, in that paper, we obtain multiplier estimates of 1.4/1.7 for the peak/cumulative effect: lower than those obtained when using nearby states' damages but broadly in line with the previously reported figures obtained with states' own damages.

\section{Robustness Checks ${ }^{26}$}

\subsection{Responses of components of fiscal variables}

To gauge better the effect of natural disasters on government spending, we analyze the responses of various fiscal variables to natural disaster shocks. We divide government expenditure and revenues into their main components and we replace government expenditure and revenues with their components one at a time. The remaining variables are the same as in the baseline model. Government spending is divided into current and capital expenditure. $^{27}$ On average, the former accounts for $92 \%$ of total state expenditure from 1977 to 2009. General revenues are split into net-revenues and intergovernmental revenues, with the former accounting for $72 \%$ of revenues during the same period. ${ }^{28}$

Figure 4 displays the impulse responses of the components of fiscal variables to one standard deviation shock due to natural disasters. For comparison, the responses of fiscal variables in the baseline model are shown too. The response of current expenditure has almost the same size and pattern as total expenditure in the baseline model. This can be attributed to the fact that it accounts for the bulk of state expenditure. Comparing the two components of expenditure, current expenditure increases steadily during the first and second years whereas capital expenditure shows a sharp increase only in the second year. This reflects the time lag of capital expenditure; current expenditure for emergency relief and assistance, in contrast, is undertaken shortly after the natural disaster. On the revenue side, although intergovernmental revenues make up 28 percent of state revenues, the response of revenues in the baseline model is more similar to that of intergovernmental revenues than to

\footnotetext{
26 The robustness checks reported in this section were obtained using the states' own damages to identify fiscal shocks (for all 50 states). The results for 48 states based on using nearby states' damages are qualitatively similar but again imply a stronger response and higher fiscal multiplier figures. These results are available upon request.

27 While current expenditure consists of all payment for current operations, transfers, subsides, and interest on debt, capital expenditure includes all expenditure for construction of buildings and other improvement and the purchase of properties. A more detailed description can be found on the Census website, at http://www2. census.gov/govs/class06/ch_5.pdf.

${ }^{28}$ Intergovernmental revenue comprises transfers from other governments, including grants, shared taxes and financial support; net-revenues are general revenues minus intergovernmental revenue, and consist of taxes and current charges: < http://www2.census.gov/govs/class06/ch_4.pdf >.
} 
net-revenues. When constructing the damages series, we select disasters based on the Presidential declarations which trigger emergency assistance from the federal government. Such assistance is part of the intergovernmental revenues, which explains why the latter peaks in the first year after the natural disaster shock. The response of net revenues mirrors the response of personal income both in magnitude and pattern rather than that of general revenues, except during the first year. This is because tax revenues are driven mainly by the overall economic activities. The remaining variables show almost same response as in the baseline model (not shown).

\subsection{Alternative measures of personal income}

First, we replace personal income with net-personal income which excludes current transfer receipts. In Figure 5, the first graph shows the response of net personal income. The responses of all other variables are nearly identical to those of the baseline model (not shown). Net personal income displays the expected hump-shaped response, peaking in the second year just like government expenditure. In addition, after three years, its response is also almost the same as that of personal income in both magnitude and pattern.

Second, we replace personal income with the Coincident Economic Activity Index (CEAI). As this index is compiled as a single summary statistic that tracks the state economy every month, it is an excellent substitute for personal income or gross state product. The second graph of Figure 5 shows the impulse response of the CEAI. The response of CEAI also appears hump-shaped. However, contrary to net-personal income, the response is significantly negative on impact and then increases for 5 years afterwards. As the trend for each state's CEAI is set to match the trend for gross state product, the CEAI includes four indicators: nonfarm payroll employment, the unemployment rate, average hours worked in manufacturing and wages and salaries. These four indicators are all closely related to the situation in the labor market. The initial negative effect therefore may be driven by the adverse effect of natural disasters on stock variables, in particular employment. In this, the response of the CEAI is very similar to that of employment in the baseline model (Figure 3). The responses of all other variables are almost the same as in the baseline model (not shown).

Third, we use the gross state product instead of personal income as the output variable. ${ }^{29}$ As explained in the section on data, using the GSP has some limitations. First, GSP is only available in annual frequency for calendar years. Therefore, it is impossible to match GSP data to fiscal years in which state fiscal variables are reported. Second, there is a break in 1997 because of a change in industry classifications. Therefore, the period from 1997 to 2009 may be too short for PVAR. The bottom graphs of Figure 5 shows the results of the model with GSP. The responses of all variables are qualitatively similar to the baseline model (not shown). However, the effects are less precisely estimated in the alternative model. This is

\footnotetext{
${ }^{29}$ In an unreported test, we similarly estimate the effects using the private gross state product (PGSP). The results are almost identical to those with GSP.
} 
especially the case of the response of GSP: it peaks on impact after the natural disaster shock and then falls, remaining positive only during the first year, in contrast to the hump-shaped response of personal income. This difference may be attributed to the limitations of GSP series mentioned above, especially the difference between fiscal and calendar years which makes identifying the shocks more difficult. As the last graph shows, when the response of GSP is shifted backward by 1 year, the responses become more similar to the baseline model.

\subsection{Frequency of natural disasters}

Next, we divide the states into two groups, according to the frequency of natural disasters. The high frequency group includes those states that experienced a natural disaster in half of the years during which we observe them, i.e. they recorded an event in 16 or more years out 33 years. 20 states belong to this group. The remaining 30 states, with less than 16 disaster years out of 33, are included in the low frequency group. Table 3 reports the summary statistics for natural disasters according to the frequency groups. The frequency of disasters in the high group is more than twice that in the low group and the average damage is more than three times larger. Therefore, while the baseline model includes 50 states, this subsection focuses on 20 states which are in the high frequency group.

Table 4 shows the impulse response of key variables to natural disasters in the high frequency group. The results are qualitatively similar to the baseline model. However, the magnitudes are much larger than those of the baseline model. This implies that the results obtained in the baseline model are driven largely by natural disasters in the high-frequency group: not surprisingly, given that few natural disasters imply lower number of government spending shocks. The peak elasticity of personal income to government expenditure is 0.29 and the cumulative elasticity for ten years is 0.09 in the high-frequency group. As the average ratio of personal income to government expenditure from 1977 to 2009 for these 20 states is 8.98 , the peak multiplier is estimated to be 2.62 and cumulative multiplier is 0.83 . The range of this multiplier is thus a little wider than that of the baseline model (1.45-2.48).

In Figure 6, we carry out a similar analysis where we divide the natural disaster data into half-year periods (defined with respect to the fiscal years rather than calendar years). The frequency of major disasters is approximately similar in the first and second half year (Table 5). However, the average damage, which reflects the size of government expenditure shocks, is over two times larger during the first half than in the second half. This reflects the fact that many natural disasters in the US are climatic, and such events are highly seasonal. The responses obtained with the first half-year damages closely follow those of the baseline model. On the other hand, the responses with the second half-year damages are quantitatively and qualitatively different from those of the baseline model. This mirrors the results obtained with the high and low frequency groups of states: given that large disasters tend to occur during the first half of fiscal year, our results are mainly driven by those observations. 


\section{Conclusions}

This paper investigates the effects of government spending shocks on key macroeconomic variables, using the increases in government spending in the wake of natural disasters to identify government spending shocks at the local (US state) level. To this effect, we construct an extensive dataset on natural disasters and the associated economic damages for all 50 states. We demonstrate that economic damages due to natural disasters can indeed be used as an instrument for government spending shocks. Natural disasters thus can shed light on the transmission process of government spending. This is a potentially important result: so far, the narrative and quasi-experimental analyses of the economic effects of government spending have relied either on discrete increases in government spending due to military buildups, or on suitably chosen natural experiments. Both of these methods have limited applicability outside of the original context: few countries have experienced a sufficient number of (extra-territorial) military conflicts to allow the former, and natural experiments are typically very rare and unique to a particular legal or historical context. In contrast, natural disasters are relatively frequent occurrences and therefore our approach could be applied to any country with a sufficient history of natural disasters and fiscal responses to them.

Furthermore, the results of our analysis confirms that government spending has a strong positive effect on the local economy: our baseline results (based on the states' own exposure to natural disasters) let us estimate the government spending peak/cumulative multiplier to be 2.5/1.5. Hence, fiscal stimuli, or austerity measures, can have dramatic economic implications.

To ensure that our results are not driven by the effects of the natural disasters themselves rather than being attributable to fiscal shocks, we repeat our analysis using economic damages due to natural disasters incurred by nearby states (rather than own damages) as an instrument for fiscal shocks. This yields qualitatively similar results as using the states' own damages, but the size of the effect, and the corresponding fiscal multiplier, are considerably higher: 7.1 and 4.0 for the peak and cumulative effects, respectively. We believe that this reflects the specific nature of our analysis, which relies on using state fiscal spending and personal income instead of overall spending and GDP. This, together with the fact that much of the increased spending after the natural disaster is financed by grants from the federal government, implies that our estimates are not directly comparable with those reported elsewhere in the literature. The fact that natural disasters experienced by nearby states (without affecting the home state) lead to increased public spending while having limited or negligible adverse effect on the home state's economy also help explain the higher values obtained with nearby states' exposure to natural disasters.

Importantly, both sets of estimates imply a strong positive effect of fiscal shocks, and the qualitative responses of the main macroeconomic variables appear similar. Further research 
can help resolve the question whether using states' own damages results in underestimating the effects of fiscal shocks because of the direct effects of the natural disasters, or whether the cross-state spillover effects when using nearby states' damages cause the effects to be overestimated. Estimates obtained with national rather than state level analysis for the US, reported in the companion paper (1.4-1.7, see Fidrmuc et al., 2015), nevertheless, are close to the multiplier estimates obtained with states' own damages, which makes us more inclined to accept the former rather than the latter view. 


\section{References}

Acconcia, A., G. Corsetti and S. Simonelli (2014). "Mafia and Public Spending: Evidence on the Fiscal Multiplier from a Quasi-Experiment." American Economic Review 104(7), 21852209.

Auerbach, A.J. and Gorodnichenko, Y. (2012). "Measuring the Output Responses to Fiscal Policy." American Economic Journal: Economic Policy 4(2), 1-27.

Barro, R., and Redlick, C. (2011), "Macroeconomic effects from government purchases and taxes", Quarterly Journal of Economics, 126, 51-102.

Bénétrix, A., and Lane, P. (2009), "The impact of fiscal shocks on the Irish economy", Economic and Social Review, 40, 407-434.

Blanchard, O., and Perotti, R. (2002), "An empirical characterization of the dynamic effects of changes in government spending and taxes on output", Quarterly Journal of Economics, $119,1329-1368$.

Burnside, C., Eichenbaum, M. and Fisher, Jonas D.M. (2004), "Fiscal shocks and their consequence", Journal of Economic Theory, 115, 89-117.

Cavallo, E., and Noy, I. (2010), “The economics of natural disasters- A survey”, IDB working paper, 124.

Congressional Budget Office (2010), "Estimated impact of the American recovery and reinvestment act on employment and economic output from October 2009 through December 2009", CBO report 4136.

Crespo Cuaresma, J., Hlouskova, J., and Obersteiner, M. (2008), "Natural disasters as creative destruction? Evidence from Developing Countries", Economic Inquiry, 46, 214-226.

Czerwinski, S. J. (1998), "Disaster assistance: Information on Federal costs and approaches for reducing them", U.S. Accounting Office's report.

Fidrmuc, J., Ghosh, S., and Yang, W., (2015). "Natural Disasters and the Fiscal Multiplier: New Evidence on US Federal Spending." Brunel University, mimeo.

Fishback, Price V., and Kachanovskaya, V. (2010), "In search of the multiplier for federal spending in the states during the new deal", NBER working paper, 16561.

Fuschs-Schündeln, N., and T.A. Hassan (2015). Natural Experiments in Macroeconomics. Goethe University Frankfurt, mimeo.

Giordano, R., Momigliano, S., Neri, S., and Perotti, R. (2007), "The effects of fiscal policy in Italy: Evidence from a VAR model”, European Journal of Political Economy, 23, 707-733.

Ilzetzki, E., Mendoza, E. G., and Végh, C. A. (2011), "How big (small?) are fiscal multipliers?", IMF working paper 11/52.

Jackson, O. (2014). “Natural Disasters, Foreign Aid, and Economic Growth.” Mimeo.

Lis, E. M., and Nickel C. (2009), "The impact of extreme weather events on budget balances and implications for fiscal policy”, European Central Bank working paper, 1055.

Loayza, N., Olaberría, E., Rigolini, J., and Christiaensen, L. (2009), "Natural disasters and growth -going beyond the averages", World Bank Policy Research Working Paper, 4980. 
Lott, N., Smith, A., Houston, T., Shein, K., and Crouch, J. (2012), "Billion Dollar U.S. Weather/Climate Disasters, 1980-2011", National Climatic Data Center (http://www.ncdc.noaa.gov/oa/reports/billionz.html).

Love, I., and Zicchino, L. (2006), "Financial development and dynamic investment behavior: evidence from panel VAR", Quarterly Review of Economics and Finance, 46, 190-210.

Mountford, A. and H. Uhlig (2009). "What are the effects of fiscal policy shocks?" Journal of Applied Econometrics 24 (6), 960-992.

Melecky, M., and Raddatz, C. (2011), "How do governments respond after catastrophes? Natural disaster shocks and the fiscal stance", World Bank Policy Research working paper, 5564.

McCarthy, Francis X. (2011), "FEMA's Disaster Declaration Process: A Primer", CRS reports for Congress, 7-5700.

Nakamura, Emi, and Steinsson, Jón (2011), "Fiscal stimulus in a monetary union: Evidence from U.S. regions", Columbia University working paper, March.

Noy, I. (2009), "The macroeconomic consequence of disasters", Journal of Development Economics, 88, 221-23.1.

Noy, I., and Nualsri, A. (2011), "Fiscal storms: public spending and revenues in the aftermath of natural disasters", Environment and Development Economics, 16, 113-128.

Perotti, R. (2005), "Estimating the effects of fiscal policy in OECD countries", CEPR discussion paper, 4842.

Raddatz, C. (2007), "Are external shocks responsible for the instability of output in lowincome countries?", Journal of Development Economics, 84, 155-187.

Raddatz, C. (2009), "The wrath of God: Macroeconomic costs of Natural disasters", World Bank Policy Research working paper, 5039.

Serrato, Juan C. S., and Wingender, P. (2010), "Estimating local fiscal multipliers", Berkeley working paper, November.

Shoag, Daniel (2010), "The impact of government spending shocks: Evidence on the multiplier from state pension plan returns", Job Market Paper.

Skidmore, M., and Toya, H. (2002), "Do natural disasters promote long-run growth?", Economic Inquiry, 40(4), 664-687.

Ramey, V. A., and Shapiro, M. D. (1998), "Costly Capital Reallocation and the Effects of Government Spending", Carnegie-Rochester Conference Series on Public Policy, 48, 145194.

Ramey, V. A. (2011a), "Identifying government spending shocks: it's all in the timing", Quarterly Journal of Economics, 126, 1-50.

Ramey, V. A. (2011b), "Can government purchase stimulate the economy?" Journal of Economic Literature, 49:3, 673-685.

Yang, W., Fidrmuc, J., and Ghosh, S. (2012a), "Macroeconomic Effects of Government Spending Shocks: New Evidence Using Natural Disaster Relief in Korea." CESIfo Working Paper No. 3943. 
Yang, W., Fidrmuc, J., and Ghosh, S. (2012b), "Government Spending Shocks and the Multiplier: New Evidence from the U.S. Based on Natural Disasters," CESIfo Working Paper No. 4005.

Yang, W., Fidrmuc, J., and Ghosh, S. (2014), "Using Military Build-ups to Capture Fiscal Shocks: A Reassessment,” CESifo Working Paper 4689. 
Table 1. Statistics for disaster damage in Top 5 frequency states

\begin{tabular}{|c|c|c|c|c|c|}
\hline & $\begin{array}{c}\text { Disaster } \\
\text { years }\end{array}$ & $\begin{array}{c}\text { Max damage } \\
\text { fiscal year } \\
\text { (million, \$) }\end{array}$ & $\begin{array}{c}\text { Number } \\
\text { of events }\end{array}$ & $\begin{array}{c}\text { Worst disaster } \\
\text { (million, \$) }\end{array}$ & $\begin{array}{c}\text { Annual damage } \\
\text { (million, \$) }\end{array}$ \\
\hline The U.S. & 33 & $\begin{array}{c}2006 \\
(158,623)\end{array}$ & 320 & $\begin{array}{c}\text { Hurricane Katrina } \\
(120,414)\end{array}$ & 17,449 \\
\hline Texas & 30 & $\begin{array}{c}2009 \\
(22,621)\end{array}$ & 73 & $\begin{array}{c}\text { Hurricane Ike } \\
(22,401)\end{array}$ & 2,057 \\
\hline California & 25 & $\begin{array}{c}1994 \\
(27,032)\end{array}$ & 61 & $\begin{array}{c}\text { LA earthquake } \\
(26,220)\end{array}$ & 2,654 \\
\hline Oklahoma & 23 & $\begin{array}{c}1999 \\
(3,662)\end{array}$ & 50 & $\begin{array}{c}\text { Extreme temperature } \\
(2,330)\end{array}$ & 402 \\
\hline Louisiana & 22 & $\begin{array}{c}2006 \\
(84,923)\end{array}$ & 41 & $\begin{array}{c}\text { Hurricane Katrina } \\
(78,682)\end{array}$ & 4,533 \\
\hline Mississippi & 21 & $\begin{array}{c}2006 \\
(39,778)\end{array}$ & 37 & $\begin{array}{c}\text { Hurricane Katrina } \\
(39,194)\end{array}$ & 2,386 \\
\hline
\end{tabular}

Notes: All damages are deflated to chained 2005 dollars and the annual damage means average total damage per state computed with year in which disaster occurred, excluding no disaster years. Disaster years refer to the number of years out of 33 in which at least one disaster occurred. Number of events is the total number of disasters during this period per state.

Table 2. Cumulative Impacts and Elasticities

\begin{tabular}{|l|c|c|c|c|c|c|}
\hline A. 50 States, Own Damages & 0 & 2 & 4 & 6 & 8 & 10 \\
\hline Year & 0.31 & 1.26 & 1.97 & 2.30 & 2.41 & 2.41 \\
\hline Gov growth rate (A, \%) & 0.14 & 0.36 & 0.59 & 0.60 & 0.51 & 0.42 \\
\hline PI growth rate (B, \%) & 0.44 & $0.28(0.30)$ & 0.30 & 0.26 & 0.21 & 0.17 \\
\hline Elasticity (B/A) & \multicolumn{5}{|l}{} \\
\hline B. 48 States, Damages to Nearby States \\
\hline Year & 0 & 2 & 4 & 6 & 8 & 10 \\
\hline Gov growth rate (A, \%) & -0.07 & 0.42 & 0.94 & 1.31 & 1.52 & 1.61 \\
\hline PI growth rate (B, \%) & 0.03 & 0.34 & 0.74 & 0.86 & 0.83 & 0.76 \\
\hline Elasticity (B/A) & -0.46 & 0.81 & $0.78(0.83)$ & 0.66 & 0.55 & 0.47 \\
\hline
\end{tabular}

Notes: The elasticities are cumulative, except for the peak effects (these are in parentheses, and only reported for the year in which the peak effect is attained).

Table 3. Average statistics for disaster per state across frequency groups

\begin{tabular}{|c|c|c|c|}
\hline & Disaster years & Number of events & Annual damage (million, \$) \\
\hline Overall average (50 states) & 13.1 & 22.7 & 632.1 \\
& $(6.50)$ & $(16.30)$ & $(1120.69)$ \\
\hline \multirow{2}{*}{ High frequency (20 states) } & 19.5 & 38.0 & $1,189.9$ \\
& $(3.49)$ & $(13.33)$ & $(1614.12)$ \\
\hline Low frequency (30 states) & 8.9 & 12.5 & 260.9 \\
& $(4.14)$ & $(7.98)$ & $(242.51)$ \\
\hline
\end{tabular}

Note: Mean values (standard deviations in parentheses). Annual damage denotes the average damage per state computed only based on years with non-zero damage due to natural disasters, excluding years without any natural disasters. 
Table 4. Response to the natural disaster and fiscal shocks

\begin{tabular}{|c|c|c|c|c|c|c|c|c|}
\hline & $0 \mathrm{yr}$ & $2 \mathrm{yrs}$ & $4 \mathrm{yrs}$ & $6 \mathrm{yrs}$ & $8 \mathrm{yrs}$ & $10 \mathrm{yrs}$ & Peak \\
\hline \multicolumn{8}{|c|}{ High frequency group (20 states) } \\
\hline Exp & $0.52^{*}$ & $0.83^{*}$ & $0.35^{*}$ & 0.05 & -0.04 & -0.04 & $0.83^{*}(2 \mathrm{yrs})$ \\
PI & $0.22^{*}$ & $0.24^{*}$ & 0.07 & $-0.09^{*}$ & $-0.11^{*}$ & $-0.09^{*}$ & $0.24^{*}(2 \mathrm{yrs})$ \\
Rev & $0.62^{*}$ & $0.91^{*}$ & $0.30^{*}$ & 0.03 & 0.00 & 0.01 & $1.07^{*}(1 \mathrm{yr})$ \\
Emply & $-0.12^{*}$ & 0.10 & -0.02 & $-0.24^{*}$ & $-0.28^{*}$ & $-0.20^{*}$ & $0.10(2 \mathrm{yrs})$ \\
\hline \multicolumn{8}{|c|}{ Baseline(50 states) } \\
\hline Exp & $0.31^{*}$ & $0.52^{*}$ & $0.30^{*}$ & $0.13^{*}$ & $0.03^{*}$ & -0.01 & $0.52^{*}(2 \mathrm{yrs})$ \\
PI & $0.14^{*}$ & $0.16^{*}$ & $0.08^{*}$ & -0.02 & $-0.05^{*}$ & $-0.04^{*}$ & $0.16^{*}(2 \mathrm{yrs})$ \\
Rev & $0.39^{*}$ & $0.56^{*}$ & $0.23^{*}$ & $0.07^{*}$ & $0.02^{*}$ & 0.00 & $0.67^{*}(1 \mathrm{yr})$ \\
Emply & $-0.07^{*}$ & $0.08^{*}$ & 0.05 & $-0.06^{*}$ & $-0.10^{*}$ & $-0.08^{*}$ & $0.09^{*}(3 \mathrm{yrs})$ \\
\hline
\end{tabular}

Note: An asterisk (*) indicates that 0 is outside the $68 \%$ confidence interval band.

Table 5. Average statistics for the first and the second half yearly damages

\begin{tabular}{|c|c|c|}
\hline & Frequency (year) & Annual damage (million, \$) \\
\hline Fiscal year & 13.1 & 632.1 \\
& $(6.50)$ & $(1120.69)$ \\
The first half year & 7.5 & 671.2 \\
& $(4.69)$ & $(1411.22)$ \\
The second half year & 9.2 & 290.3 \\
& $(5.64)$ & $(393.97)$ \\
\hline
\end{tabular}

Note: Standard deviations in parentheses. All damages costs are deflated in chained 2005 dollars. 
Figure 1. The trend of natural disasters in the U.S. from 1980 to 2010

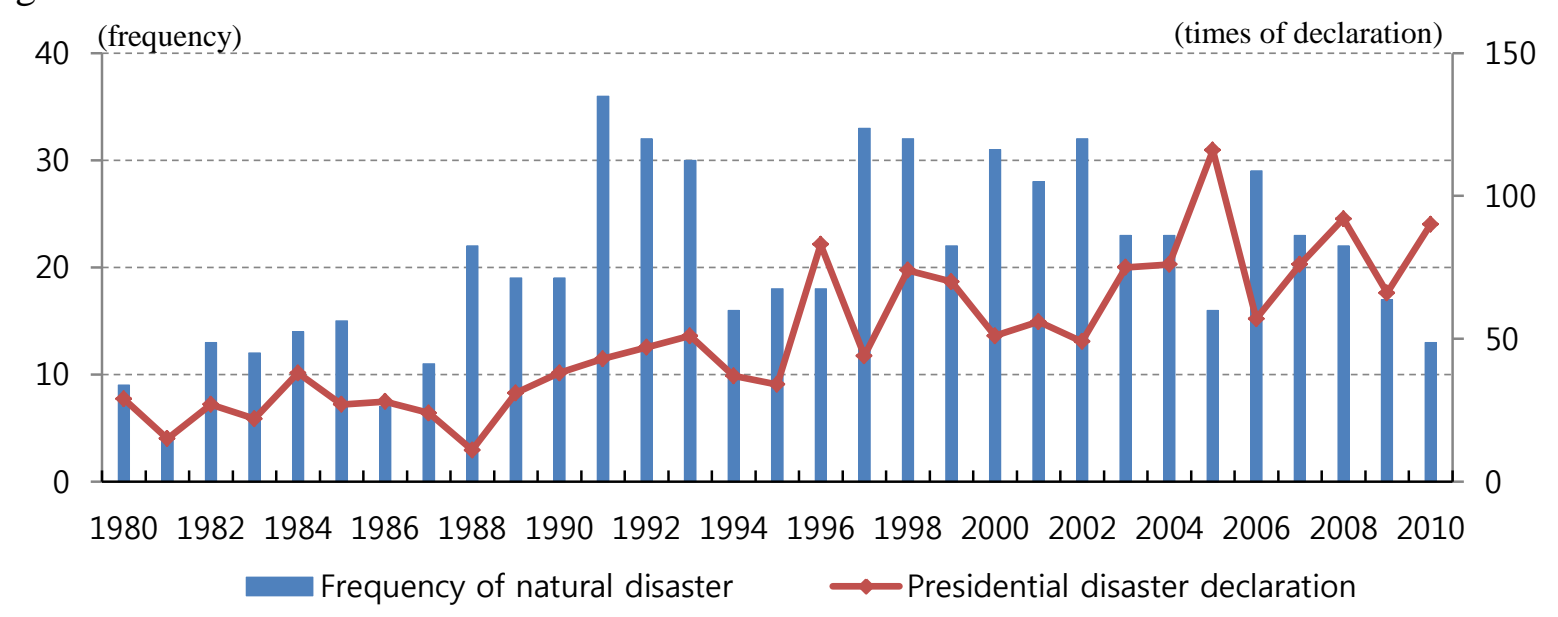


Figure 2. Baseline Results: Impulse-Response to Government Spending Shocks, 50 States

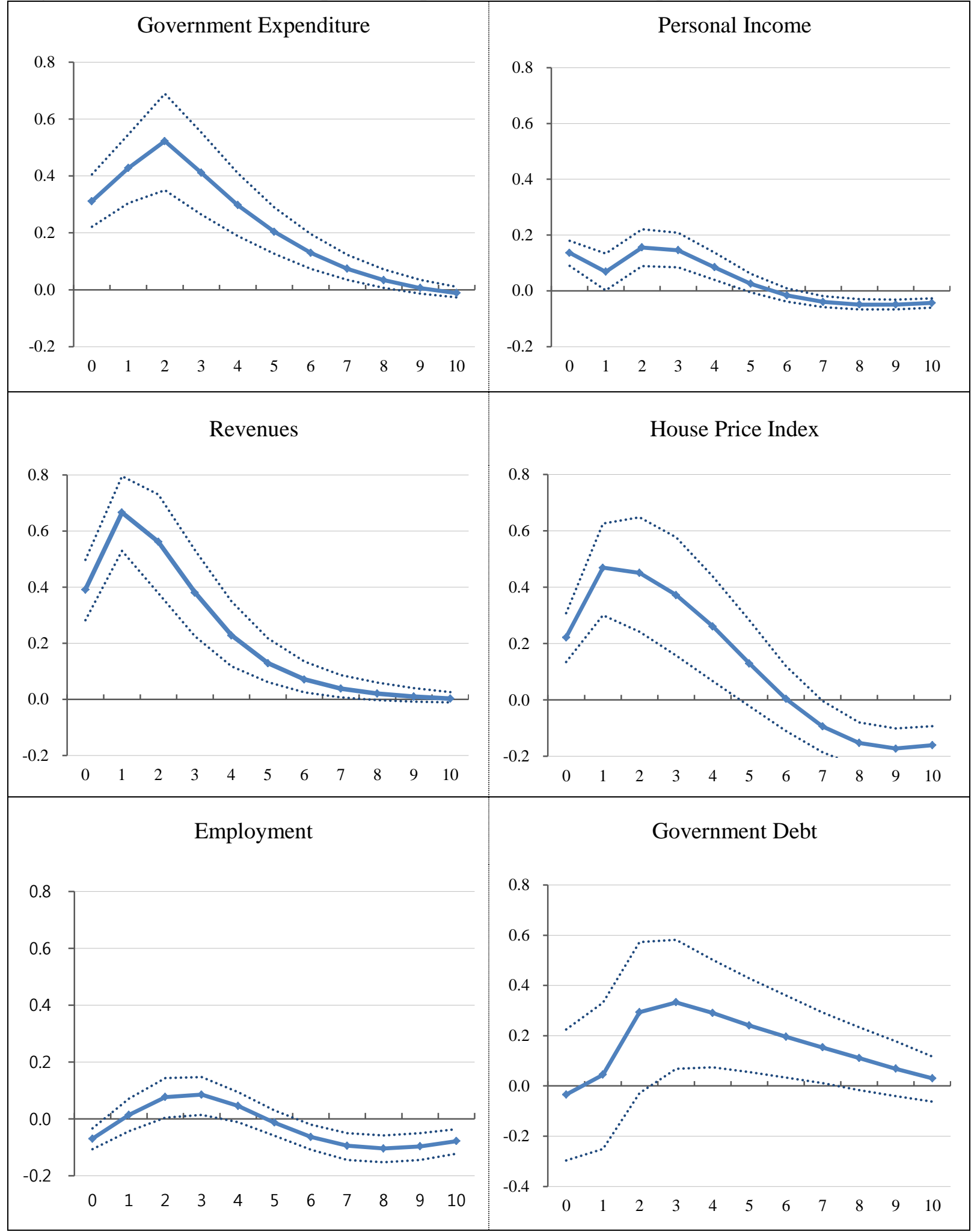

Note: 50 US states. Solid lines display point estimates while the dashed lines correspond to $68 \%$ confidence interval bands. 
Figure 3. Impulse-Response to Government Spending Shocks, 48 States, Fiscal Shocks Instrumented by Damages to Nearby States

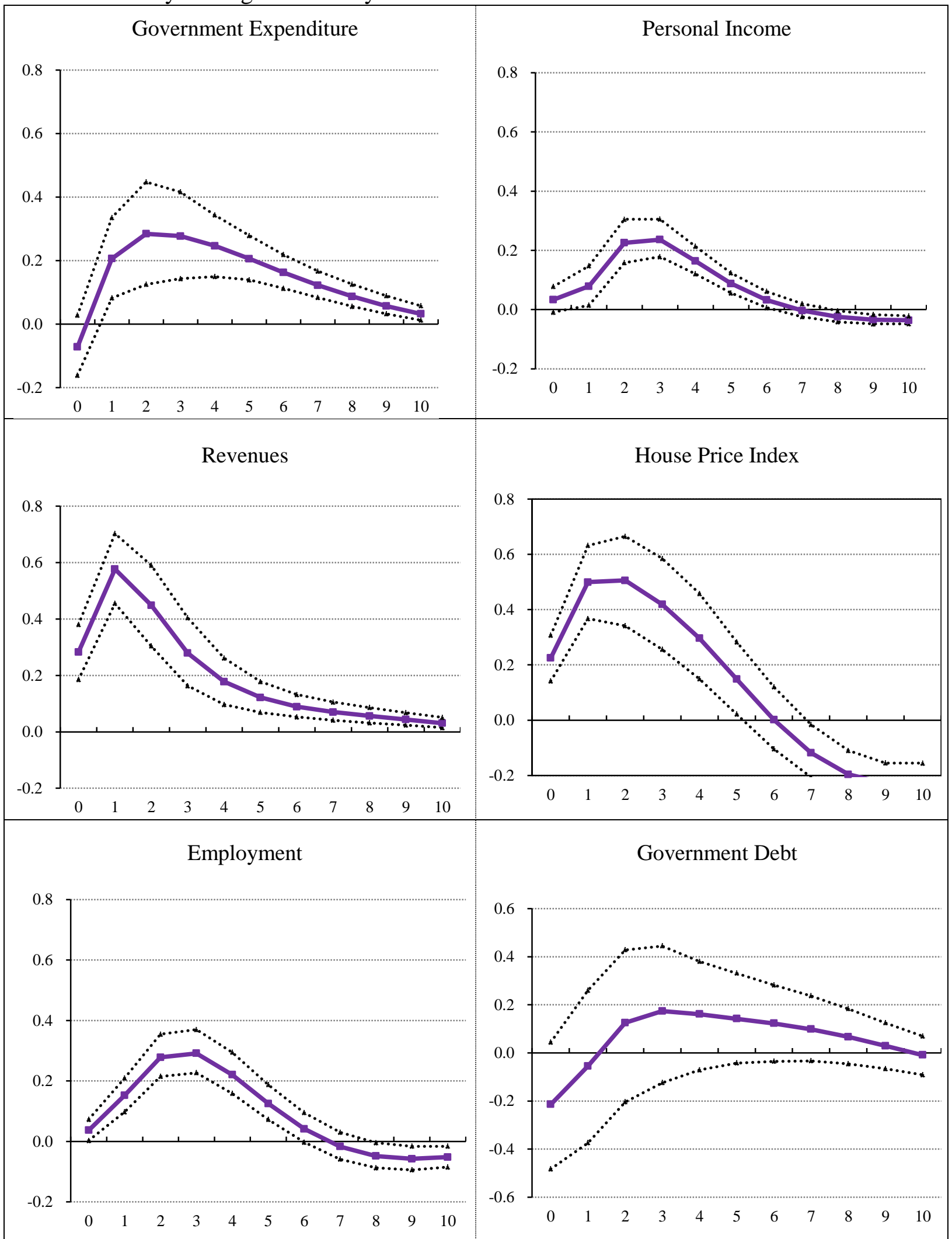

Note: 48 Continental US states. Solid lines display point estimates while the dashed lines correspond to $68 \%$ confidence interval bands. Nearby states are those within $1,000 \mathrm{~km}$ straight distance (capital to capital). 
Figure 4. Response of fiscal components to the natural disaster

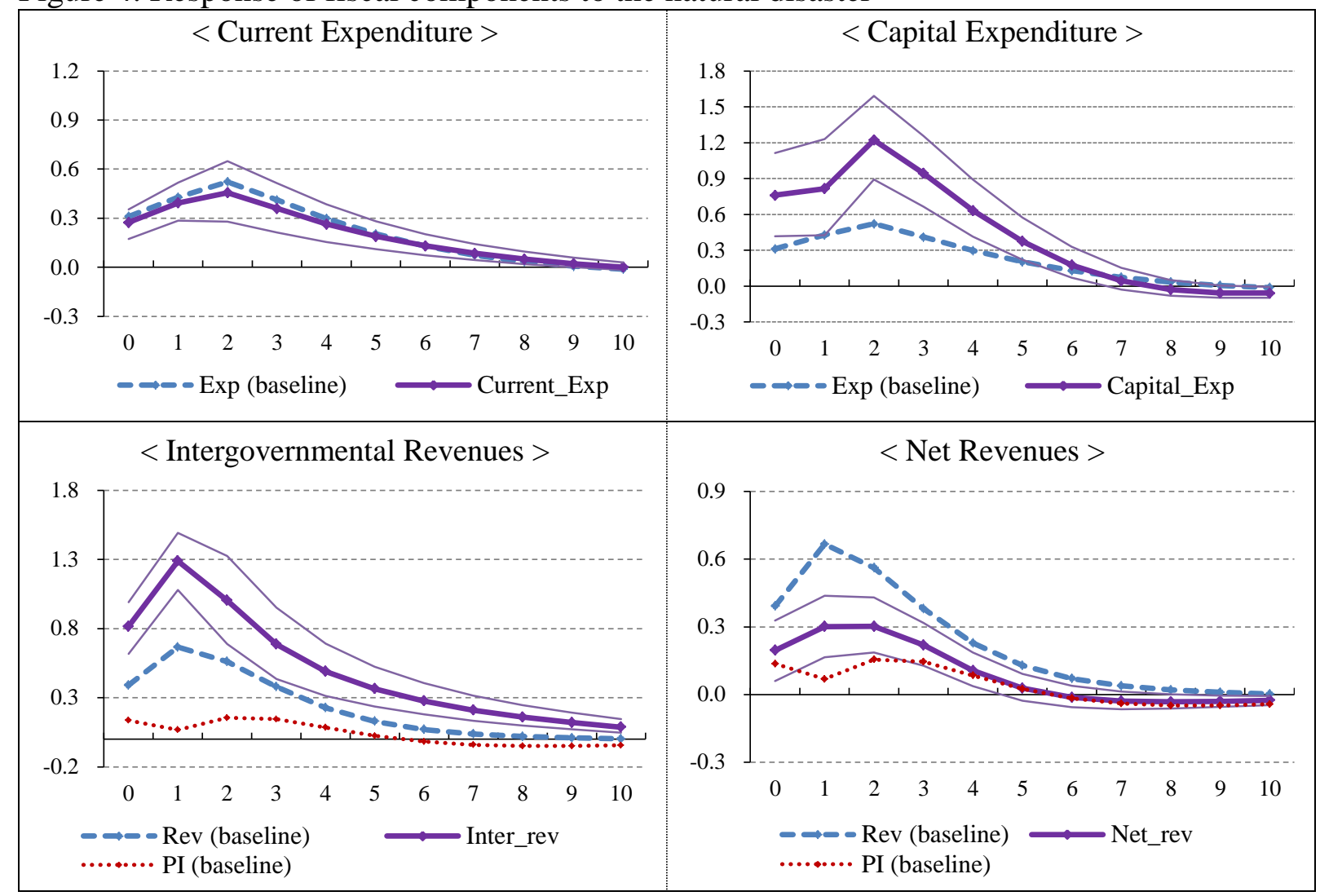

Figure 5. Responses with alternative income/output variables

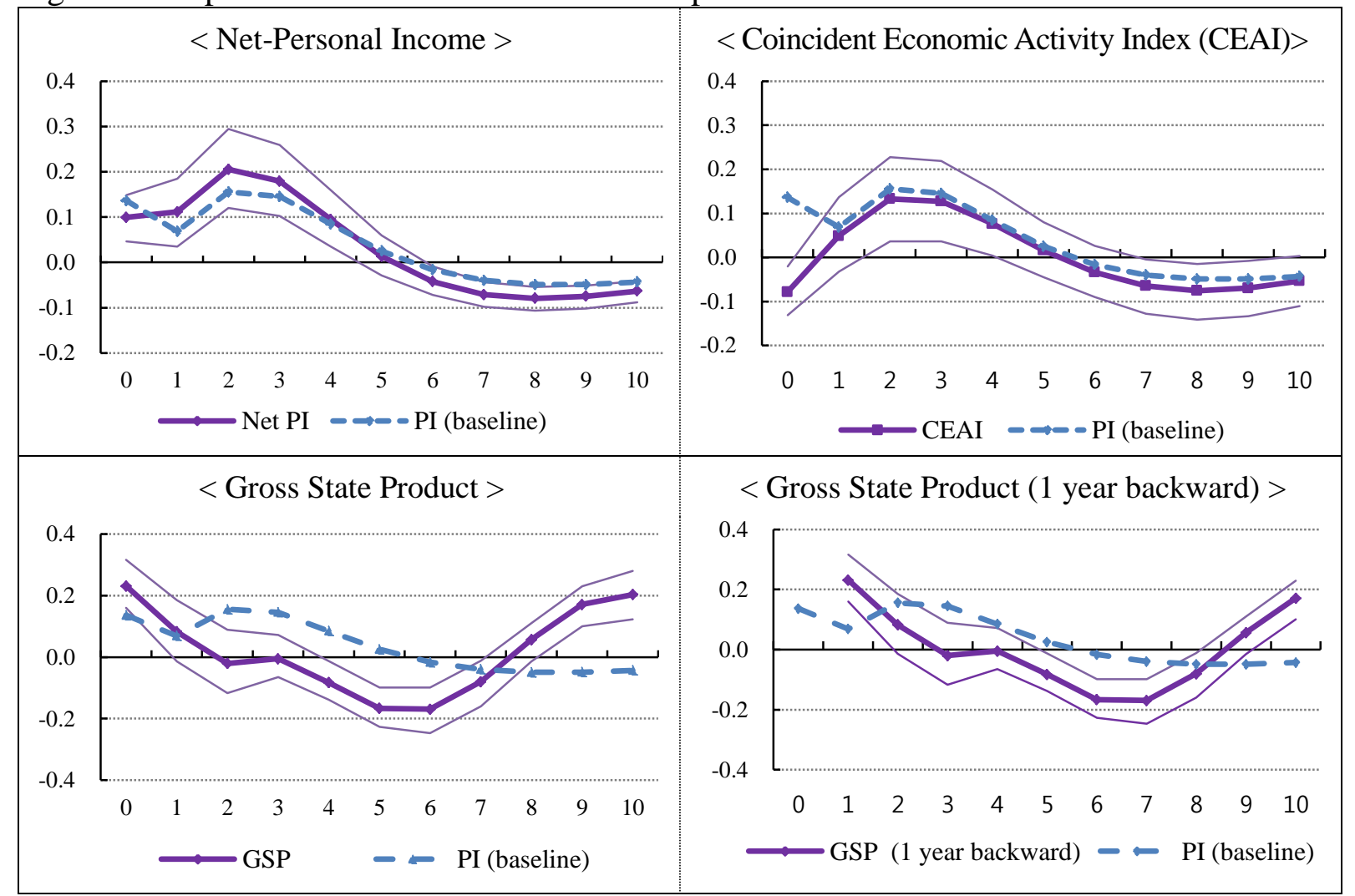


Figure 6. Alternative models with the first and the second half yearly damages

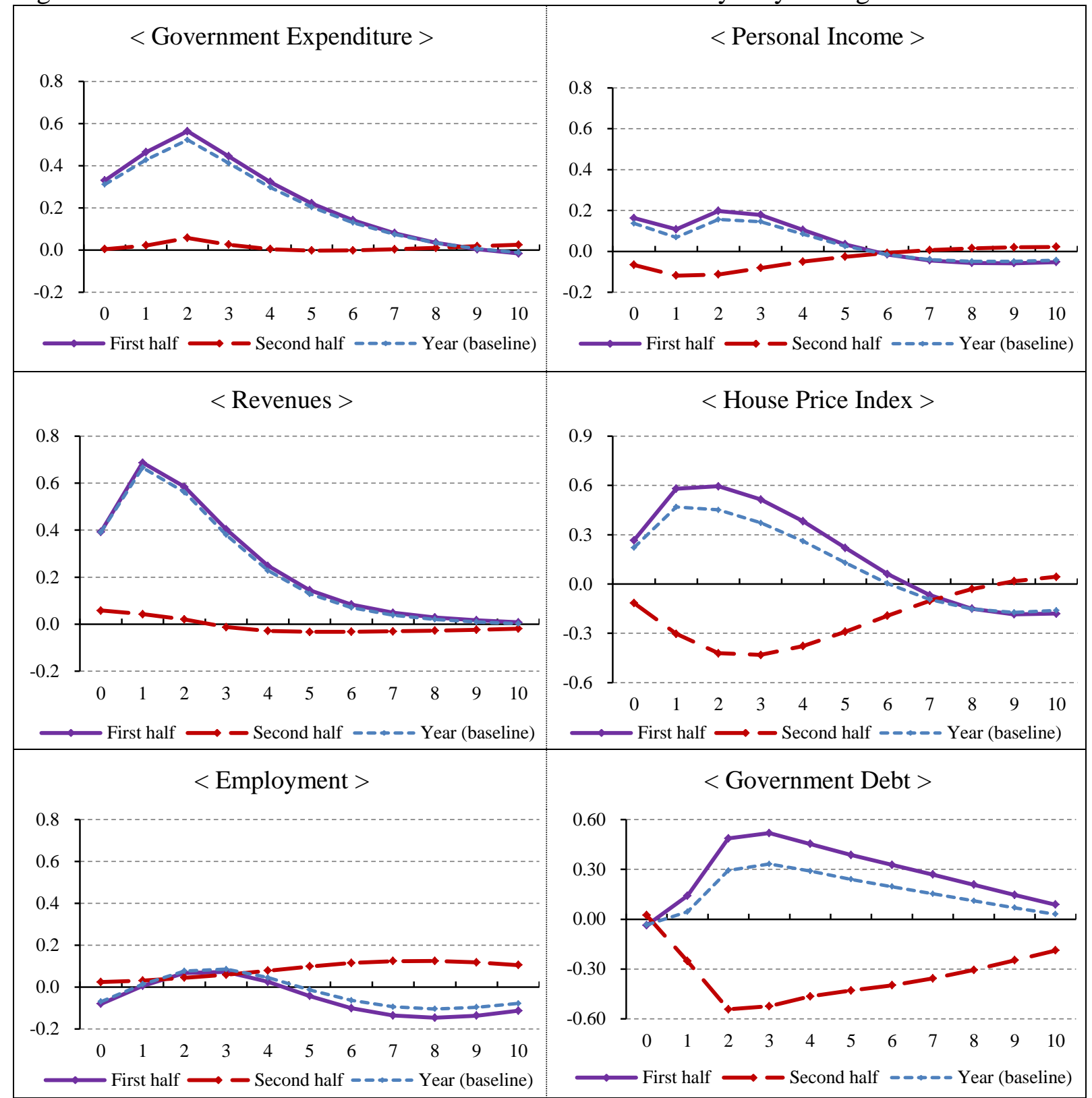




\section{Appendices for Online Publication}

\section{A. The economic damages due to natural disasters in the U.S}

\begin{tabular}{|c|c|c|c|c|c|c|c|c|}
\hline Quarter & Damage & $\begin{array}{c}\text { Dam/GDP } \\
(\%)\end{array}$ & Quarter & Damage & $\begin{array}{c}\text { Dam/GDP } \\
(\%)\end{array}$ & Quarter & Damage & $\begin{array}{c}\text { Dam/GDP } \\
(\%)\end{array}$ \\
\hline $77.1 q$ & 1.00 & 0.02 & $88.1 q$ & 0.06 & 0.00 & $99.1 \mathrm{q}$ & 1.89 & 0.02 \\
\hline $77.2 q$ & 1.49 & 0.03 & $88.2 q$ & 0.03 & 0.00 & $99.2 q$ & 2.57 & 0.02 \\
\hline $77.3 q$ & 0.90 & 0.02 & $88.3 q$ & 0.00 & 0.00 & $99.3 q$ & 3.03 & 0.03 \\
\hline $77.4 q$ & 0.27 & 0.00 & $88.4 q$ & 0.11 & 0.00 & $99.4 q$ & 7.41 & 0.07 \\
\hline $78.1 \mathrm{q}$ & 1.96 & 0.04 & $89.1 \mathrm{q}$ & 0.00 & 0.00 & $00.1 \mathrm{q}$ & 0.65 & 0.01 \\
\hline $78.2 q$ & 0.00 & 0.00 & $89.2 q$ & 0.60 & 0.01 & $00.2 q$ & 2.35 & 0.02 \\
\hline $78.3 q$ & 0.49 & 0.01 & $89.3 q$ & 0.79 & 0.01 & $00.3 q$ & 1.44 & 0.01 \\
\hline $78.4 q$ & 0.33 & 0.01 & $89.4 q$ & 19.79 & 0.25 & $00.4 q$ & 2.81 & 0.02 \\
\hline $79.1 q$ & 0.00 & 0.00 & $90.1 \mathrm{q}$ & 0.24 & 0.00 & $01.1 \mathrm{q}$ & 3.11 & 0.03 \\
\hline $79.2 q$ & 2.61 & 0.04 & $90.2 q$ & 0.76 & 0.01 & $01.2 q$ & 8.47 & 0.07 \\
\hline $79.3 q$ & 6.14 & 0.10 & $90.3 q$ & 0.00 & 0.00 & $01.3 q$ & 0.02 & 0.00 \\
\hline $79.4 q$ & 0.59 & 0.01 & $90.4 q$ & 0.05 & 0.00 & $01.4 q$ & 0.05 & 0.00 \\
\hline $80.1 \mathrm{q}$ & 0.87 & 0.01 & $91.1 \mathrm{q}$ & 5.58 & 0.07 & $02.1 \mathrm{q}$ & 0.46 & 0.00 \\
\hline $80.2 q$ & 3.49 & 0.06 & $91.2 q$ & 0.90 & 0.01 & $02.2 q$ & 2.19 & 0.02 \\
\hline $80.3 q$ & 6.28 & 0.11 & $91.3 \mathrm{q}$ & 3.88 & 0.05 & $02.3 q$ & 2.14 & 0.02 \\
\hline $80.4 q$ & 0.00 & 0.00 & $91.4 \mathrm{q}$ & 3.91 & 0.05 & $02.4 q$ & 2.26 & 0.02 \\
\hline $81.1 \mathrm{q}$ & 0.00 & 0.00 & $92.1 \mathrm{q}$ & 1.32 & 0.02 & $03.1 \mathrm{q}$ & 0.51 & 0.00 \\
\hline $81.2 q$ & 0.96 & 0.02 & $92.2 q$ & 0.25 & 0.00 & $03.2 q$ & 6.60 & 0.06 \\
\hline $81.3 q$ & 0.98 & 0.02 & $92.3 q$ & 39.37 & 0.47 & $03.3 q$ & 4.20 & 0.04 \\
\hline $81.4 \mathrm{q}$ & 0.24 & 0.00 & $92.4 q$ & 3.31 & 0.04 & $03.4 q$ & 2.55 & 0.02 \\
\hline $82.1 \mathrm{q}$ & 0.71 & 0.01 & $93.1 \mathrm{q}$ & 7.43 & 0.09 & $04.1 q$ & 0.00 & 0.00 \\
\hline $82.2 q$ & 1.75 & 0.03 & $93.2 q$ & 1.56 & 0.02 & $04.2 q$ & 1.25 & 0.01 \\
\hline $82.3 q$ & 0.12 & 0.00 & $93.3 q$ & 15.56 & 0.18 & $04.3 q$ & 39.65 & 0.32 \\
\hline $82.4 \mathrm{q}$ & 1.28 & 0.02 & $93.4 \mathrm{q}$ & 0.87 & 0.01 & $04.4 \mathrm{q}$ & 7.09 & 0.06 \\
\hline $83.1 \mathrm{q}$ & 1.72 & 0.03 & $94.1 q$ & 31.15 & 0.36 & $05.1 \mathrm{q}$ & 1.35 & 0.01 \\
\hline $83.2 q$ & 1.50 & 0.02 & $94.2 \mathrm{q}$ & 0.82 & 0.01 & $05.2 q$ & 0.37 & 0.00 \\
\hline $83.3 \mathrm{q}$ & 3.93 & 0.06 & $94.3 \mathrm{q}$ & 0.61 & 0.01 & $05.3 q$ & 128.32 & 1.01 \\
\hline $83.4 \mathrm{q}$ & 1.04 & 0.02 & $94.4 q$ & 1.47 & 0.02 & $05.4 q$ & 16.45 & 0.13 \\
\hline $84.1 \mathrm{q}$ & 0.19 & 0.00 & $95.1 \mathrm{q}$ & 3.71 & 0.04 & $06.1 q$ & 0.52 & 0.00 \\
\hline $84.2 \mathrm{q}$ & 5.48 & 0.08 & $95.2 q$ & 5.27 & 0.06 & $06.2 q$ & 2.03 & 0.02 \\
\hline $84.3 \mathrm{q}$ & 0.76 & 0.01 & $95.3 q$ & 1.31 & 0.01 & $06.3 q$ & 1.02 & 0.01 \\
\hline $84.4 \mathrm{q}$ & 0.00 & 0.00 & $95.4 \mathrm{q}$ & 4.52 & 0.05 & $06.4 \mathrm{q}$ & 0.36 & 0.00 \\
\hline $85.1 \mathrm{q}$ & 2.24 & 0.03 & $96.1 \mathrm{q}$ & 1.74 & 0.02 & $07.1 \mathrm{q}$ & 0.90 & 0.01 \\
\hline $85.2 q$ & 1.36 & 0.02 & $96.2 q$ & 0.27 & 0.00 & $07.2 q$ & 1.20 & 0.01 \\
\hline $85.3 \mathrm{q}$ & 2.39 & 0.03 & $96.3 q$ & 5.02 & 0.05 & $07.3 q$ & 0.59 & 0.00 \\
\hline $85.4 \mathrm{q}$ & 7.40 & 0.11 & $96.4 q$ & 0.26 & 0.00 & $07.4 \mathrm{q}$ & 1.90 & 0.01 \\
\hline $86.1 \mathrm{q}$ & 0.79 & 0.01 & $97.1 \mathrm{q}$ & 3.46 & 0.04 & $08.1 q$ & 1.43 & 0.01 \\
\hline $86.2 q$ & 0.05 & 0.00 & $97.2 q$ & 6.10 & 0.06 & $08.2 q$ & 3.31 & 0.02 \\
\hline $86.3 q$ & 1.26 & 0.02 & $97.3 q$ & 0.52 & 0.01 & $08.3 q$ & 2.66 & 0.02 \\
\hline $86.4 \mathrm{q}$ & 0.00 & 0.00 & $97.4 q$ & 0.03 & 0.00 & $08.4 \mathrm{q}$ & 14.85 & 0.12 \\
\hline $87.1 \mathrm{q}$ & 0.00 & 0.00 & $98.1 \mathrm{q}$ & 3.24 & 0.03 & $09.1 q$ & 0.48 & 0.00 \\
\hline $87.2 q$ & 0.28 & 0.00 & $98.2 q$ & 3.53 & 0.03 & $09.2 q$ & 0.73 & 0.01 \\
\hline $87.3 q$ & 0.26 & 0.00 & $98.3 q$ & 8.05 & 0.08 & $09.3 q$ & 0.23 & 0.00 \\
\hline $87.4 \mathrm{q}$ & 0.57 & 0.01 & $98.4 q$ & 2.37 & 0.02 & $09.4 q$ & 0.13 & 0.00 \\
\hline
\end{tabular}

* Damages are expressed in real terms using the CPI $(2005=100)$ 


\section{B. Data Sources}

\section{Natural disaster}

\begin{tabular}{|l|l|l|}
\hline \multicolumn{1}{|c|}{ Data } & \multicolumn{1}{c|}{ Source } & \multicolumn{1}{c|}{ Website } \\
\hline Disaster list & $\begin{array}{l}\text { Emergency Disaster Database } \\
\text { (CRED) }\end{array}$ & http://www.emdat.be \\
\hline $\begin{array}{l}\text { Federal disaster } \\
\text { declaration list }\end{array}$ & $\begin{array}{l}\text { Federal Emergency } \\
\text { Management Agency (FEMA) }\end{array}$ & http://www.fema.gov/disasters \\
\hline Billion \$ disaster list & National Climate Data Center & http://www.ncdc.noaa.gov/billions \\
\hline Disaster damages report & National Hurricane Center & http://www.nhc.noa.gov \\
\hline Disaster damages report & National Weather Service & http://www.weather.gov \\
\hline Disaster damages report & Storm prediction center & http://www.spc.noaa.gov \\
\hline Storm Events Database & National Climate Data Center & http://www.ncdc.noaa.gov/stormevents \\
\hline
\end{tabular}

\section{State level variables}

\begin{tabular}{|l|l|l|}
\hline \multicolumn{1}{|c|}{ Series } & \multicolumn{1}{|c|}{ Source } & \multicolumn{1}{c|}{ Description } \\
\hline Government expenditure & State government finance (CB) & Nominal series deflated by CPI \\
\hline Revenues & State government finance $(\mathrm{CB})$ & Nominal series deflated by CPI \\
\hline Personal income & Regional data (BEA) & Nominal series deflated by CPI \\
\hline House price index & State HPI data (FHFA), & Index (2005=100) \\
\hline Employment & Economic data (FRB) & Non-farm payroll, Quarterly data \\
\hline Government debt & State government finance (CB) & Nominal series deflated by CPI \\
\hline $\begin{array}{l}\text { Gross state product } \\
\text { Coincident Economic } \\
\text { Activity Index }\end{array}$ & Regional data (BEA) & Real series, chained (2005) dollars \\
\hline State population & Population estimates (BEA) & Index (1992=100) \\
\hline
\end{tabular}




\section{C. $68 \%$ vs $90 \%$ confidence bands of the results at the state level}

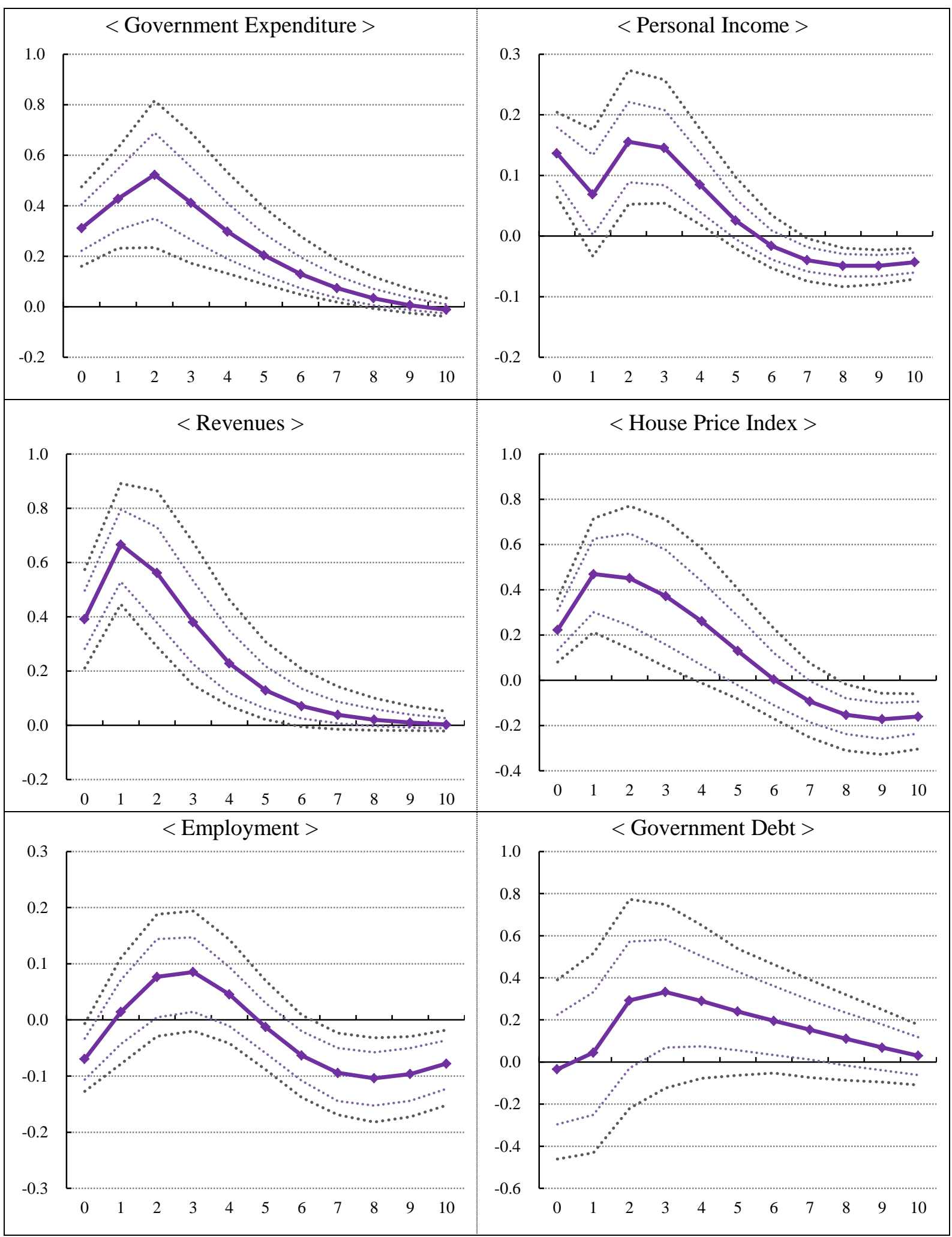

